\title{
CASE REPORT \\ Mesenteric metastasis of granulosa cell tumor in a bitch: a case report
}

\author{
Metástasis mesentérica de tumor de células de granulosa en una perra: reporte de caso \\ Metástase mesentérica de tumor das células da granulosa em uma cadela: relato de caso
}

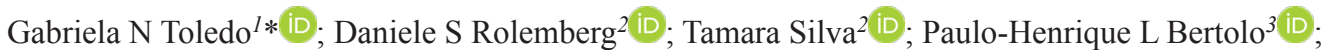

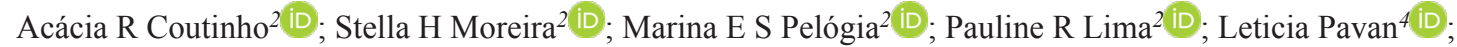
Paola C Moraes $^{2}$ (D); Rosemeri O Vasconcelos ${ }^{3}$ id; Andrigo B De-Nardi²
\end{abstract}

\footnotetext{
${ }^{1}$ Universidade Federal de Campina Grande (UFCG) - Centro de Saúde e Tecnologia Rural (CSTR) - Patos, PB, Brazil.

${ }^{2}$ Universidade Estadual de São Paulo “Julio de Mesquita Filho” - Faculdade de Ciências Agrárias e Veterinárias (UNESP/FCAV),

Departamento de Clínica e Cirurgia Veterinária, Jaboticabal, SP, Brazil.

${ }^{3}$ Universidade Estadual de São Paulo “Julio de Mesquita Filho” - Faculdade de Ciências Agrárias e Veterinárias (UNESP/FCAV),

Departamento de Patologia Veterinária, Jaboticabal, SP, Brazil.

${ }^{4}$ Universidade Estadual de São Paulo “Julio de Mesquita Filho” - Faculdade de Ciências Agrárias e Veterinárias (UNESP/FCAV),

Departamento de Obstetrícia e Reprodução Animal, Jaboticabal, SP, Brazil.
}

To cite this article:

Toledo GN, Rolemberg DS, Silva T, Bertolo PHL, Coutinho AR, Moreira SH, Pelógia MES, Lima PR, Pavan L, Moraes PC, Vasconcelos RO, De-Nardi AB. Mesenteric metastasis of granulosa cell tumor in a bitch: a case report. Rev Colomb Cienc Pecu 2021; 34(3): 231-239. DOI: https://doi.org/10.17533/udea.rccp.v34n3a07

\section{Abstract}

Anamnesis: A 5-year-old mixed breed entire bitch was presented with bloody vaginal discharge and abdominal distension. Clinical and laboratory findings: Physical examination and abdominal ultrasonography suggested the presence of a left ovarian tumor. At histopathological examination it was diagnosed as granulosa cell tumor. Treatment approach: An exploratory laparotomy was performed followed by ovariohysterectomy to remove the intra-abdominal mass. Conclusion: The clinical, ultrasonographic and histologic signs in this case support other literature reports. Ultrasonography, in combination with histopathologic analysis is a fundamental tool for detection of ovarian tumors, especially tumors of the granulosa cells.

Keywords: bitch; canine; carcinoma; echography; granulosa; histopathology; histology; neoplasia; reproductive system, ovary; ovarian cancer; ovarian tumor; tumor; ultrasound; ultrasonography; vaginal discharge; veterinary pathology.

Received: April 6, 2020; accepted: August 19, 2020

*Corresponding author. Universitaria Av, s/n, Patos, PB, Brazil. Tel.: + 5516 991918112. E-mail: bitoledo@hotmail.com

Postal Code: $58708-110$ 


\section{Resumen}

Anamnesis: Una perra entera sin raza definida, con cinco años de edad, presentando secreción vaginal sanguinolenta con una distensión abdominal acentuada. Hallazgos clínicos y de laboratorio: El examen clínico y la ultrasonografía abdominal sugirieron la presencia de la neoformación ovárica izquierda. En el examen histopatológico fue diagnosticado como tumor de células de la granulosa. Aproximación terapéutica: Se realizó una laparotomía exploratoria seguida de ovariohisterectomía para eliminar la masa intra-abdominal. Conclusión: Los signos clínicos, ecográficos e histológicos en este caso respaldan otros informes de la literatura. La ecografía, en combinación con el análisis histopatológico, es una herramienta fundamental para la detección de tumores ováricos, especialmente tumores de las células de la granulosa.

Palabras clave: cáncer de ovario; cáncer ovárico; canino; carcinoma; descarga vaginal; ecografía; granulosa; histopatología; histología; neoplasia; patología veterinaria; perra; sistema reproductivo; ovario; tumor; tumor ovárico; ultrasonido; ultrasonografía.

\section{Resumo}

Anamnese: Uma cadela sem raça definida, com cinco anos de idade, não castrada, apresentando secreção vaginal sanguinolenta com acentuada distensão abdominal. Achados clínicos e laboratoriais: O exame clínico e ultrassonografia abdominal sugeriram a presença de neoformação ovariana esquerda. No exame histopatológico foi diagnosticado como tumor de células da granulosa. Abordagem terapêutica: Foi realizada laparotomia exploratória seguida de ovariohisterectomia para remoção da massa intra-abdominal. Conclusão: Os sinais clínicos, ultrassonográficos e histológicos corroboram a literatura, concluindo que a modalidade ultrassonográfica, em associação a análise histopatológica é uma ferramenta fundamental na detecção de neoformações ovarianas, contribuindo significativamente no diagnóstico final.

Palavras-chave: cadela; câncer; cancro do ovário; carcinoma; canina; corrimento vaginal; ecografia; granulosa; histologia; histopatologia; patologia veterinária; ovário; sistema reprodutor; tumor ovariano; ultrassom; ultrassonografia. 


\section{Introduction}

Metastatic behavior of sex cord-stromal tumors, whereas metastases are relatively common in queens and slightly less so in bitches, may occur in regional lymph nodes through the hematogenous route to other organs or, rarely, by implantation of neoplastic cells in the peritoneum (Agnew and MacLachlan, 2017).

Typically, granulosa cell tumors (GCT) arise in entire bitches and queens from two to 10 years of age. Although rare in neutered females, they may occur in bitches with remaining ovarian tissue due to incomplete ovariohysterectomy $(\mathrm{OH}$; Sivacolundhu et al., 2001; Daleck et al.,2016).

The GCT originate from the sex cord-stroma of the ovarian granulosa cells (Agnew and MacLachlan, 2017). They have a low incidence $(0.5$ to $6.25 \%)$ in neutered females and make up 0.5 to $1.2 \%$ of all canine tumors (Dow, 1960; Klein, 2013; Banco et al., 2011).

Most common clinical signs result from high estrogen concentrations produced by the tumor, with continuous estrus, bloody vulvar discharge, vulvar hyperplasia, pseudo-pregnancy, cystic endometrial hyperplasia, pyometra, alopecia, and hyperpigmentation (Zanghi et al., 2007; Agnew and MacLachlan, 2017). The high levels of estrogen are also responsible for bone marrow suppression, which leads to thrombocytopenia and non-regenerative anemia (Agnew and MacLachlan, 2017; Santos et al., 2017). Additionally, hyperadrenocorticism has been reported in a bitch with ovarian sex cordstromal tumor (Agnew and MacLachlan, 2017).

Ultrasonography is an excellent tool for examination of the abdominal cavity in veterinary medicine (Terragni et al., 2014). A presumptive diagnosis of GCT can be made using ultrasonography, which provides reliable and relevant information regarding the dimensions, contours, echogenicity, echotexture, and vascularization of the patient's internal structures (Tessler et al., 1989).
Uterine wall changes, such as irregularities, thickening, and circular and presence of anechoic structures, are frequently associated with GCT. Intraluminal filling by anechoic or hypoechoic contents are also reported in the literature, suggesting the possibility of cystic endometrial hyperplasia or pyometra in association with neoplastic disease (Diez-Bru et al., 2018).

Surgery remains the basis of treatment for ovarian tumors. A complete ovariohysterectomy is recommended, although oophorectomy alone is possible. Careful examination of the other abdominal organs should be performed, including the omentum and diaphragm. Biopsy of lesions where metastatic disease is suspected is recommended for staging purposes. Adjuvant chemotherapy has been reported, but there is no consensus on the best protocol. Radiotherapy is rarely indicated or used in dogs because the disease is usually confined to the ovary and there is a high success rate following surgery (Klein, 2013).

Therefore, the aim of this study was to describe the ultrasound findings and clinical manifestations in a bitch affected by GCT. The importance of diagnostic imaging for this pathology is emphasized.

\section{Patient examination}

\section{Anamnesis}

A 5-year old, entire female cross-breed dog, weighing $22.6 \mathrm{~kg}$ was admitted at the Veterinary Hospital of the School of Agrarian and Veterinary Sciences - São Paulo State University (FCAV / UNESP, Brazil). A seven-day history of bloody vaginal discharge and abdominal distension was recorded.

\section{Clinical findings and diagnostic aids}

On abdominal palpation, a structure with irregular borders was detected in the left mesogastric area. The fluid wave test was positive, suggesting the presence of abdominal effusion. Further examinations were performed 
to rule out systemic abnormalities. Blood samples revealed neutrophilic leukocytosis $(32.0 \mathrm{~K} / \mu \mathrm{l}$ : reference value $6.0-18.0 \mathrm{~K} / \mu \mathrm{l})$. Biochemistry analysis was within normal ranges.

Ultrasonographic examination was performed with the patient in the supine position using a linear transducer. The abdominal cavity was examined systematically in a counterclockwise direction. A large $(7.61 \times 6.32 \mathrm{~cm})$, rounded, heterogeneous, circumscribed mass with defined borders and regular contours was detected on the left side. The mass was in the left mesogastric region, in the position of the ovary.

A cavity with defined and regular borders was found in the cranial portion of the mass, filled with anechoic contents and several punctate structures in suspension without back acoustic shading, suggesting cellular sediment. The ultrasound examination confirmed the suspicion of a left ovarian tumor (Figure 1A).

In a similar position on the right, a rounded anechoic structure with defined and regular borders was also observed surrounded by homogeneous and hyperechoic tissue (omentum). This structure contained a discrete amount of cellular sediment and was $0.77 \mathrm{~cm}$ in diameter (Figure 1B).

The thickening and irregularity of the wall of both uterine horns was evident. In association with this finding, several circumscribed and intramural anechoic structures and a small amount of homogeneous and intraluminal anechoic content was observed, suggesting cystic endometrial hyperplasia (Figure 2C).

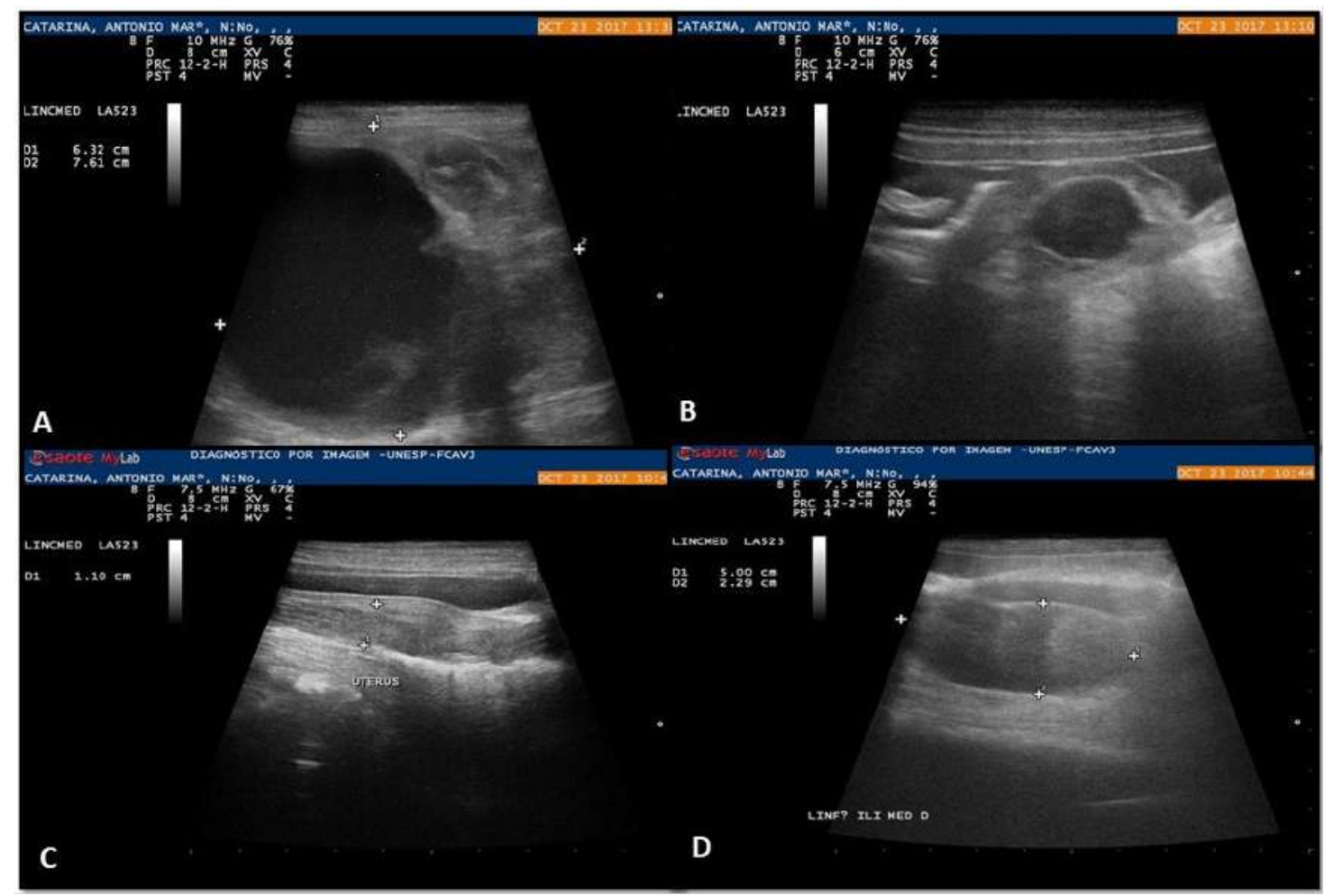

Figure 1. Ultrasonographic images of the abdomen of a five-year-old bitch with GCT. A: Left mesogastric region. Note a circumscribed heterogeneous mass with regular borders, with an anechoic circumscribed area in its cranial portion. The sedimentary content does not form a posterior acoustic shadow, suggesting a cavitary or a cystic formation (*). B: An anechogenic structure was observed, with a small amount of sediment, hyperechogenic wall, surrounded by omentum, in the right ovary region, measuring $0.77 \mathrm{~cm}$ in diameter $\left(^{*}\right)$. C: Enlarged uterine body $(1.10 \mathrm{~cm})$ with discrete anechoic circumscribed areas, most evident in its cranial portion (cystic endometrial hyperplasia) $(*)$. D: Enlarged right medial iliac lymph node $(5 \times 2.29 \mathrm{~cm})$ with preserved borders, echotexture, and echogenicity, suggesting an inflammatory reaction or an infiltrative lesion (*). 
Ultrasonographically, the medial iliac lymph nodes were enlarged (right: $6.32 \times 2.39 \mathrm{~cm}$, left: $3.17 \times 1.10 \mathrm{~cm}$; Figure 1D) suggestive of inflammatory reaction or, less likely, neoplastic infiltration.

A moderate amount of free abdominal fluid was present outlining the intestinal loops and other intra-abdominal structures. Abdominocentesis of the ascitic fluid and fine needle aspirates of material from the lymph nodes were obtained by guided aspiration and were classified as exudate and inflammatory reaction, respectively.

Thoracic radiographs in three views (right, left and ventrodorsal) were performed. There were no visible metastases in the pulmonary parenchyma and no abnormalities were detected in other intrathoracic structures.

\section{Treatment approach}

Surgical resection of the intra-abdominal mass was planned. A $10 \mathrm{~cm}$ mass was removed, corresponding to the left ovary. After removal, serosanguinous fluid drained from the cranial portion of the tumor.

Suspected metastatic lesions were noted in the left kidney and peritoneum alongside the left ovary. The nodules were biopsied for later histopathologic analysis.

\section{Postoperatively Dipirona ${ }^{\circledR} \quad 25 \mathrm{mg} / \mathrm{kg}$} $\mathrm{TID} / 5 \mathrm{~d}$, ranitidine hydrochloride $2 \mathrm{mg} / \mathrm{kg}$ $\mathrm{BID} / 10 \mathrm{~d}$, cephalexin $30 \mathrm{mg} / \mathrm{kg} \mathrm{BID} / 10 \mathrm{~d}$, and metronidazole $15 \mathrm{mg} / \mathrm{kg}$ BID/10 d were prescribed, with reevaluation seven days after surgery.

Samples of peritoneum, ovaries and uterus were sent for histopathological analysis. Macroscopically, the peritoneum showed multifocal, soft and yellow nodules, and the ovaries presented whitish focal area and cysts. The uterus had a heterogeneous, whitish and cystic surface.
Microscopic analysis of the ovaries showed neoplastic proliferation of granulosa cells, infiltrative growth, cells in follicular pattern, sometimes cystic, some cells with luteinized appearance (Figure 2A) and 22 mitotic figures were observed in 10 high-power field (Figure 2B). The histopathological diagnosis confirmed GCT. Focus of the tumor were observed in the peritoneum fragment. The uterus presented cystic endometrial hyperplasia.

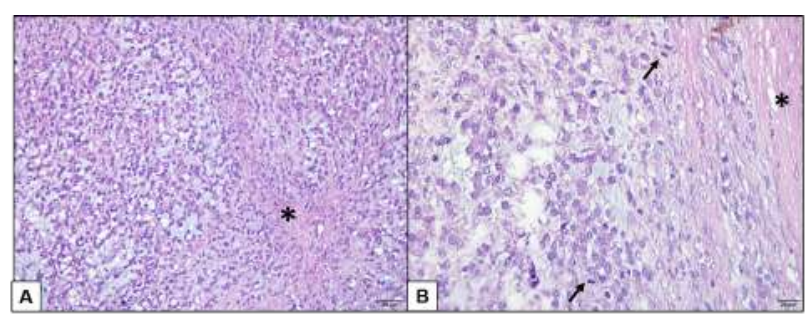

Figure 2. Granulosa cell tumor in a bitch ovary. A: Neoplastic proliferation of granulosa cells with high cellularity in a discrete fibrous stroma $(*)$. The cells are arranged in a solid pattern and in some places the tumor cells acquire a luteinized appearance. Hematoxylin-Eosin $($ Bar $=50 \mu \mathrm{m})$. B: Tumor well delimited by fibrous connective tissue $(*)$, several mitotic figures (arrows). Hematoxylin-Eosin $(\mathrm{Bar}=20 \mu \mathrm{m})$.

The owner declined chemotherapy on the grounds of cost. The patient died six months after diagnosis.

\section{Discussion}

Ovarian tumors are uncommon in bitches, with an incidence of $6.25 \%$ in intact females and $<1 \%$ in neutered females (Ball et al., 2010; Omori et al., 2015; Daleck et al., 2016). Ovarian tumors are divided into four categories: epithelial, stromal, germ cell and mesenchymal tumors (from non-gonadal tissues around the ovaries; Agnew and MacLachlan, 2017). The patient in this report was diagnosed with GCT, an uncommon tumor that can be seen in entire bitches or those with remnant ovarian tissue and with no breed preference.

Persistent bloody vaginal discharge is a common clinical sign in dogs with GCT. Additionally, persistent estrus or proestrus occurs due to estradiol or progesterone release by the tumor (Sivacolundhu et al., 2001). The 
clinical signs in this case included abdominal distension, bloody vaginal discharge and hyporexia. These findings agree with those described by other researchers (Bolson and Pachaly, 2004; Foster, 2013; Spoor et al., 2014; Santos et al., 2017).

Cystic endometrial hyperplasia is commonly reported in association with GCT and reflects the effects of estrogen or progesterone on the endometrium (Sivacolundhu et al., 2001). In some cases, it may be associated with squamous metaplasia; however, no association with endometrial malignancy has been documented. In a study of ovarian tumors, endometrial hyperplasia was described in all dogs with GCT $(12 / 12)$, suggesting that the estrogenic effect and high concentrations of sex hormones occur in GCT cases (Patnaik and Greenle, 1987). Our results agree with those described by the researchers mentioned above.

Neutrophilic leukocytosis was observed on a blood sample, a finding expected in bitches with cystic endometrial hyperplasia (Kim et al., 2012; Spoor et al., 2014). Cystic endometrial hyperplasia syndrome stimulates a local inflammatory reaction and the hyperplastic endometrium may accumulate secretions, in which bacterial infection can become established (Schlafer and Gifford, 2008). In the present report, although neutrophilic leukocytosis was described, no bacterial infection was diagnosed, possibly due to the short evolution time of cystic endometrial hyperplasia.

Patients with GCT may develop pancytopenia due to hormonal imbalance and paraneoplastic syndrome due to suppression of the bone marrow induced by hyperestrogenism (Daleck et al., 2016; Agnew and MacLachlan, 2017). These alterations were not observed in this case. However, pancytopenia is not pathognomonic for ovarian tumors (Daleck et al., 2016).

In a previous study, seven cases of GCT were diagnosed by cytology, followed by histopathological confirmation. The cells were isolated and did not form papillary clusters.
The individual cells were round, oval, and polyhedral. The cytoplasm was vacuolated, with a single nucleolus and discrete cellular atypia and variable amount of vacuolated cytoplasm. In some cases, some cells had abundant and non-vacuolated cytoplasm, like luteinized gonadal cells (Daleck et al., 2016). Cytological examination is a reliable tool in the diagnosis of certain types of canine ovarian tumors. In this case, no neoplastic cells were observed at cytological analysis.

However, some researchers claim that cytology of ovarian masses, especially of cystic malignancies, can result in seeding of neoplastic cells in the abdominal cavity. Thus, it is advised that trans-abdominal cytology should only be performed on suspected ovarian tumors when there are not recurrent infections, no metastasis or in patients where body condition does not allow exploratory laparotomy (Stanley et al., 1991). In the present study, although cytology of ovarian tumor neoplasia was not performed, the patient already had implantation of neoplastic cells in the peritoneum, confirmed on histopathological examination.

The main ultrasonographic imaging findings of GCT was an echogenic mass with a regular surface in the region of the ovary. However, they have also been reported to have irregular surface formed by the presence of cystic areas filled with anechoic content (Souza et al., 2005; Kim et al., 2012).

In a study where two cases of canine GCT were evaluated, the ultrasonographic changes described were large masses with irregular borders, the presence of nodules with hypoechoic foci and some anechoic areas, as well as alteration in mass echogenicity (Sivacolundhu et al., 2001; Zanghi et al., 2007). In another study, the ultrasonographic changes included presence of cystic structures with hyperechoic fluid lateral to ovary and cysts in the parenchyma of both ovaries (Kim et al., 2012).

In another report, ultrasound examination allowed identification of cystic formations in 
both ovaries (Diez-Bru et al., 2018). Although these researchers report low frequency of bilateral involvement of ovarian tumors, except in cases of carcinomatous tumors, and rarity of metastasis of ovarian neoformation in the peritoneum, in the present report we describe the presence of both lesions. Late detection of the ovarian tumor could have led to the advanced neoplastic development, with regional metastasis.

The presence of moderate amount of free anechoic fluid in the abdomen also corroborates the findings in the mentioned case (Diez-Bru et al., 2018), in which free anechoic content was seen on examination of $5 / 10$ bitches with ovarian tumors, analyzed ultrasonographically and histopathologically. Presence of free fluid suggests involvement of the lymphatic pathways by metastasis of neoplastic cells. This finding is common in patients with advanced ovarian tumors (Diez-Bru et al., 2018).

The GCT have both lymphatic and hematogenous metastatic potential. Thus, GCT may affect several abdominal structures, such as liver, spleen, kidneys, pancreas, adrenals, gastrointestinal tract, uterus and mesenteric lymph nodes (Lissoir et al., 2001). In this case, metastasis was seen on ultrasonographic examination, where discrete heterogeneous areas, with poorly defined and regular borders in the left renal cortex were observed. In addition, on exploratory laparotomy, foci of neoplastic implantation in the peritoneum and left kidney were reported. Due to these changes, the prognosis was guarded.

Definitive diagnosis was made on histopathologic analysis. The ovarian cells were arranged in a follicular pattern with cystic formations surrounded by several layers of cells with hemorrhagic and acidophilic contents, in the middle of a discrete stroma of fibrous tissue. Our findings were similar to those previously described in the veterinary literature (González et al., 2005; Kim et al., 2012; Agnew and MacLachlan, 2017).
In conclusion, this case demonstrates that ultrasound examination is useful in the presumptive diagnosis of ovarian tumor, although specificity for ovarian tumor type is low. GCT have a cystic pattern and can be diagnosed by ultrasonography, but veterinary ultrasonographers should take care to examine follicular structures carefully and take into account the breed before declaring the cystic appearance to be abnormal. Moreover, patients with a clinical history of infertility and changes in the time of proestrus or estrus should be investigated and GCT should be included on differential diagnosis. It is also important to consider location of the mass and previous history of $\mathrm{OH}$ since ovarian tumors cannot be ruled out despite a previous history of $\mathrm{OH}$. Finally, mesenteric metastases can result in serious complications due to the possibility of intestinal obstruction, ischemia or perforation. Some factors such as age, tumor size, biological behavior and the presence of distant metastases may determine the prognosis and survival time of dogs with intra-abdominal tumors.

\section{Declaration}

\section{Acknowledgements}

The authors would like to acknowledge the Department of Clinic and Veterinary Surgery of the School of Agrarian and Veterinary Sciences - São Paulo State University (FCAV-UNESP, Brazil) for the support provided during the study.

\section{Funding}

This research did not receive any specific grant from funding agencies in the public, commercial, or not-for-profit sectors.

\section{Conflict of interest statement}

The authors declare they have no conflicts of interest with regard to the work presented in this report. 


\section{Author contributions}

Gabriela N Toledo: manuscript preparation, interpretation of data, collection and analysis, design. Daniele S Rolemberg: imaging tests and writing, interpretation of data. Tamara Silva: imaging tests and writing, interpretation of data, collection and analysis. Paulo $\mathrm{H} \mathrm{L}$ Bertolo: interpretation of data, collection and analysis, pathology writing, design. Acácia $\mathrm{R}$ Coutinho: imaging tests and writing, collection and analysis. Stella H Moreira: interpretation of data, collection and analysis. Marina E S Pelógia: imaging tests and writing, interpretation of data.

Pauline R Lima: interpretation of data, collection and analysis. Leticia Pavan: imaging tests and writing, collection and analysis. Paola C Moraes: interpretation of data, manuscript preparation.

Rosemeri O Vasconcelos: interpretation of data, pathology writing. Andrigo B De Nardi: interpretation of data, manuscript preparation. Júlio C Canola: interpretation of data, manuscript preparation.

\section{References}

Agnew DW, MacLachlan J. Tumors of the genital system. In: Meuten DJ, editor. Tumors in Domestic Animals. 4th ed. Ames: Iowa State Press; 2017, p. 689-722. DOI: https://doi.org/10.1002/9781119181200.ch16

Ball RL, Birchard SJ, May LR, Threlfall WR, Young GS. Ovarian remnant syndrome in dogs and cats: 21 cases (2000-2007). J Am Vet Med Assoc 2010; 236(5): 548-553. DOI: https://doi.org/ 10.2460/javma.236.5.548

Banco B, Antuofermo E, Borzacchiello G, CossuRocca P, Griecco V. Canine ovarian tumors: an immunohistochemical study with HBME-1 antibody. J Vet Diagn Invest 2011; 23(5): 977-981. DOI: https://doi.org/10.1177/1040638711416848

Bolson J, Pachaly JR. Hiperestrogenismo secundário a tumor ovariano em cadela (Canis familiaris, Linnaeus, 1758) - relato de caso. Arq Ciênc Vet Zool UNIPAR 2004; 7(2): 175-9. DOI: https://doi.org/10.25110/arqvet.v7i2.2004.86

Daleck CR, Souza FF, Martins MIM, De Nardi AB. Neoplasias do sistema reprodutor feminino. In: Daleck CR e De Nardi AB. Oncologia em cães e gatos. 2nd ed. Rio de Janeiro: Guanabara Koogan; 2016, p. 545-556. ISBN: 9788527729918.

Diez-Bru N, Gracia-Real I, Martinez EM, Rollan E, Mayenco A, Llorens P. Ultrasonographic appearance of ovarian tumors in 10 dogs. Vet Radiol Ultrasound 2018; 39(3): 223-236. DOI: https://doi.org/10.1111/j.1740-8261.1998.tb00345.x

Dow C. Ovarian abnormalities in the bitch. J Comp Pathol 1960; 70: 59-69. DOI: https://doi. org/10.1016/s0368-1742(60)80005-7

Foster RA. Sistema reprodutor feminino e glândula mamária. In: Zachary JF, McGavin MD. Bases da Patologia em Veterinária. 5th ed. Rio de Janeiro: Saraiva; 2013, p. 1088-1129.

GonzálezMS,FernándezL,SaldarriagaS,Aranzazu D, Maldonado JG. Infertilidad en una perra con historia de falla reproductiva recurrente asociada con tumor de células de la granulosa. Rev Colom Cienc Pecua. 2005; 18(3): 258-268. Available from $<$ http://www.scielo.org.co/scielo.php?script=sci arttext\&pid $=$ S012006902005000300007 \&lng=en\&nrm=iso $>$ Access on 18 Mar. 2020.

Kim H, Choi H, Kim H, Choi J. A giant parovarian cyst in a dog with a granulosa cell tumor. J Vet Med Sci 2012; 74(3): 385-389. DOI: https://doi.org/ 10.1292/jvms.11-0414

Klein MK. Tumors of the female reproductive system. In: Withrow SJ, Vail DM. 5th ed. Small animal clinical oncology. Saint Louis: Elsevier Saunders; 2013, p.610-617. DOI: https://doi.org/10.1016/B978-0-7216-0558-6. $\underline{\mathrm{X} 5001-1}$

Lissoir JD, Berthiaume MJ, Boudez G, Nguyen TV, Alaire G. Bone metastasis from a granulosa cell tumor of the ovary. Gynecol Oncol 2001; 83(2): 400-404. DOI: https://doi.org/10.1006/gyno.2001.6367 
Omori M, Kondo T, Yuminamochi T, Nakazawa K, Ishii Y, Fukasawa H, Hashi A, Hirata S. Cytologic features of ovarian granulosa cell tumors in pleural and ascitic fluids. Diagno Cytopathol 2015; 43(7): 581-584. DOI: https://doi.org/ 10.1002/dc.23248

Patnaik AK, Greenle PG. Canine ovarian neoplasms: a clinicopathologic study of 71 cases, including histology of 12 granulosa cell tumors. Vet Pathol 1987; 24(6): 509-514. DOI: https://doi.org/ 10.1177/030098588702400607

Santos RL, Nascimento EF, Edwards JF. Sistema reprodutor feminino. In: Santos RL and Alessi AC. Patologia veterinária. 2nd ed. Rio de Janeiro: Roca; 2017, p. 751-804. ISBN: 9788527729246.

Schlafer DH, Gifford AT. Cystic endometrial hyperplasia, pseudo-placentational endometrial hyperplasia, and other cysticconditions of the canine and feline uterus. Theriogenology 2008; 70 (3): 349-358. DOI: https://doi.org/10.1016/j.theriogenology.2008.04.041

Sivacolundhu RK, O'Hara AJ, Read RA. Granulosa cell tumour in two spayed bitches. Aust Vet J 2001; 79(3): 173-176. DOI: https://doi.org/10.1111/j.1751-0813.2001.tb14571.x

Spoor MS, Flesner BK, Trzil JE, Whitney MS, Shaw D P, Selting K A. What is your diagnosis? Intra-abdominal mass in a female spayed dog.
Vet Clin Pathol 2014; 43(1): 109-110. DOI: https://doi.org/0.1111/vcp.12104

Souza HJM, Amorim FV, Jaffé E. Timoma e tumor de células da granulosa em gata. Acta Sci Vet 2005; 33 (5): 211-217. DOI: https://doi.org/10.22456/1679-9216.14828

Stanley MW, Horwitz CA, Frable WJ. Cellular follicular cyst of the ovary: fluid cytology mimicking malignancy. Diagn Cytopathol 1991; 7(1): 48-52. DOI: https://doi.org/10.1002/dc.2840070119

Terragni R, Vignoli M, Van Bree HJ, Gaschen L, Saunders JH. Diagnostic imaging and endoscopic findingin dogs and cats with gastrictumors: areview. SchweizArch Tierheilkd, 2014; 156(12): 569-576. DOI: https://doi.org/ 10.1024/0036-7281/a000652

Tessler FN, Schiller VL, Perrella RR, Sutherland ML, Grant EG. Transabdominal versus endovaginal pelvic sonography: prospective study. Radiology, 1989; 70(2): 553-556. DOI: https://doi.org/ 10.1148/radiology.170.2.2643149

Zanghi A, Catone G, Marino G, Quartuccio M, Nicotina PA. Endometrial polypoid adenomyomatosis in a bitch with ovarian granulosa cell tumour and pyometra. J Comp Pathol 2007; 136(1): 83-86. DOI: https://doi.org/ 10.1016/j.jppa.2006.11.004 